\title{
Sugarcane response to nitrogen rates, measured by a canopy reflectance sensor
}

\author{
Hugo José Andrade Rosa(1), Lucas Rios do Amaral(2), José Paulo Molin ${ }^{(1)}$ and Heitor Cantarella(3)
}

\begin{abstract}
(1)Universidade de São Paulo, Escola Superior de Agricultura Luiz de Queiroz, Departamento de Engenharia de Biosistemas, Avenida Pádua Dias, no 11, CEP 13418-900 Piracicaba, SP, Brazil. E-mail: hugo.jar@hotmail.com, jpmolin@usp.br (2)Universidade Estadual de Campinas, Faculdade de Engenharia Agrícola, Avenida Cândido Rondon, no 501, CEP 13083-875 Campinas, SP, Brazil. E-mail: lucas.amaral@feagri.unicamp.br ${ }^{(3)}$ Instituto Agronômico, Centro de Pesquisa e Desenvolvimento de Solos e Recursos Ambientais, Avenida Barão de Itapura, no 1.481, CEP 13020-902 Campinas, SP, Brazil. E-mail: cantarella@iac.sp.gov.br
\end{abstract}

\begin{abstract}
The objective of this work was to evaluate whether a canopy sensor is capable of estimating sugarcane response to $\mathrm{N}$, as well as to propose strategies for handling the data generated by this device during the decision-making process for crop $\mathrm{N}$ fertilization. Four $\mathrm{N}$ rate-response experiments were carried out, with $\mathrm{N}$ rates varying from 0 to $240 \mathrm{~kg} \mathrm{ha}^{-1}$. Two evaluations with the canopy sensor were performed when the plants reached average stalk height of 0.3 and $0.5 \mathrm{~m}$. Only two experiments showed stalk yield response to $\mathrm{N}$ rates. The canopy sensor was able to identify the crop response to different $\mathrm{N}$ rates and the relationship of the nutrient with sugarcane yield. The response index values obtained from the canopy sensor readings were useful in assessing sugarcane response to the applied $\mathrm{N}$ rate. Canopy reflectance sensors can help to identify areas responsive to $\mathrm{N}$ fertilization and, therefore, improve sugarcane fertilizer management.
\end{abstract}

Index terms: NDVI, nitrogen fertilization, optical sensor, precision agriculture, proximal sensing.

\section{Resposta da cana-de-açúcar a doses de nitrogênio estimada por sensor de refletância do dossel}

Resumo - O objetivo deste trabalho foi avaliar se um sensor de dossel é capaz de estimar a resposta da cana-de-açúcar ao $\mathrm{N}$, bem como propor estratégias para tratar os dados gerados pelo equipamento durante o processo de tomada de decisão para a adubação nitrogenada da cultura. Foram conduzidos quatro experimentos de dose-resposta ao $\mathrm{N}$, com doses de $\mathrm{N}$ que variaram de 0 a $240 \mathrm{~kg} \mathrm{ha}^{-1}$. Duas avaliações foram realizadas com o sensor de dossel quando as plantas alcançaram altura média de colmos de 0,3 e 0,5 m. Apenas dois experimentos mostraram resposta ao $\mathrm{N}$ aplicado em termos de produtividade de colmos. O sensor foi capaz de identificar a resposta da cultura a diferentes doses de $\mathrm{N}$ e a relação do nutriente com a produtividade da cana. Os índices de resposta obtidos pelas leituras do sensor foram úteis em avaliar a resposta da cana-de-açúcar ao $\mathrm{N}$ aplicado. Sensores de dossel podem auxiliar na identificação de áreas responsivas à aplicação de $\mathrm{N} \mathrm{e}$, consequentemente, melhorar o manejo da fertilização nitrogenada da cana-de-açúcar.

Termos para indexação: NDVI, adubação nitrogenada, sensor óptico, agricultura de precisão, sensoriamento proximal.

\section{Introduction}

The complexity of nitrogen environmental dynamics makes $\mathrm{N}$ fertilization management one of the most difficult tasks in agriculture (Van Raij, 2011). A broad variation in $\mathrm{N}$ response and utilization (Gava et al., 2003; Prado \& Pancelli, 2008) has been reported particularly in sugarcane (Saccharum officinarum L.) crops, although the general acceptance is that $\mathrm{N}$ use is usually low, with values around 10 to $15 \%$ of the total $\mathrm{N}$ absorbed by the plant (Franco et al., 2011). However, Cantarella et al. (2007) argued that despite the low $\mathrm{N}$ response measured in individual experiments, sugarcane shows important response to $\mathrm{N}$ fertilization when group of experiments are jointly analyzed.

Nitrogen deficiency has negative consequences on sugarcane plant development and on crop yield (Cantarella et al., 2007), but its excess can also be detrimental to the crop, causing a decrease in sugar levels and late ripening (Thorburn et al., 2005). Therefore, considering the complex $\mathrm{N}$ dynamics in sugarcane production systems and the absence of a reliable soil test to predict $\mathrm{N}$ response (Cantarella, 2007), a device capable of modelling plant response 
to management practices and to climate conditions is crucial to improve $\mathrm{N}$ use efficiency.

Crop canopy reflectance sensors (canopy sensors) are tools used in precision agriculture for this purpose. The initial motivation of the first studies with this equipment was mainly sustainable land management. Currently, the potential of canopy sensors in rationalizing costs has also been acknowledged, since they allow adjusting $\mathrm{N}$ fertilization by identifying $\mathrm{N}$ uptake capacity, $\mathrm{N}$ demand, and the crop response to the nutrient (Olfs et al., 2005; Mullen et al., 2010).

Despite the potential usage of canopy sensors in sugarcane, this subject remains relatively unexplored. In a pioneer study in Brazil, Molin et al. (2010) found that a canopy sensor was able to differentiate $\mathrm{N}$ rates applied to sugarcane, whereas in the USA, Lofton et al. (2012a) showed that the response of stalk yield to $\mathrm{N}$ fertilization could be estimated by the same canopy sensor. In a more recent study, Amaral \& Molin (2014) concluded that the canopy sensor was a useful device in identifying $\mathrm{N}$ variability within production areas, which made it possible to apply the nutrient at variable rates.

However, few studies evaluate and propose new usage techniques for canopy sensors in sugarcane, which can be a difficult task due to the complexity of $\mathrm{N}$ soil dynamics and to the variation in crop response to applied N. Therefore, a detailed evaluation of the commercially-available solutions is important.

The objective of this work was to evaluate whether a canopy sensor is capable of estimating sugarcane response to $\mathrm{N}$, as well as to propose strategies for handling the information generated by this device in the decision-making process for crop $\mathrm{N}$ fertilization.

\section{Materials and Methods}

Four plot experiments were conducted during the 2011/2012 agricultural year to assess sugarcane response to different $\mathrm{N}$ rates, in fields under rainfed conditions and covered with straw from the unburned previous harvest (Table 1).

The first two experiments were conducted at the experimental stations of Instituto Agronômico in the municipalities of Piracicaba and Jaú, respectively, in the state of São Paulo, Brazil. Both crops were second ratoons that had been receiving the same treatments since the plant cane cycle. The experimental design was a randomized complete block in split-plots, with four replicates. The plots contained three different varieties of sugarcane (Table 1) and were formed by five 40-m long rows. The split-plots were formed by five 10-m long rows, and the treatment consisted of three $\mathrm{N}$ rates $\left(50,100\right.$, and $\left.150 \mathrm{~kg} \mathrm{ha}^{-1}\right)$ plus a control without $\mathrm{N}$ application. The $\mathrm{N}$ fertilizer was manually applied near the ratoon plants on top of the straw cover, using ammonium sulphate as $\mathrm{N}$ source.

The third and fourth experiments were conducted in the municipality of Pradópolis, in the state of São Paulo, Brazil, in commercial sugarcane fields. The experimental design was a randomized complete block with four replicates. In this case, each plot was formed by six $15-\mathrm{m}$ long rows. The $\mathrm{N}$ treatment was applied only during the experimental year and consisted of four $\mathrm{N}$ rates $\left(60,120,180\right.$, and $\left.240 \mathrm{~kg} \mathrm{ha}^{-1}\right)$ plus a control without $\mathrm{N}$ application. Ammonium nitrate was manually applied near the ratoon plants on top of the straw cover. Phosphorus and potassium fertilization, as well as weed control, were common to all plots and followed the recommendations for sugarcane in the region.

The canopy sensor used was the GreenSeeker RT200 (Trimble Navigation Limited, Sunnyvale, CA, USA). This sensor emits modulated light centered in two wavelengths: visible red light $(660 \pm 15 \mathrm{~nm})$ and near-infrared $(770 \pm 15 \mathrm{~nm})$, with an emission frequency around $40,000 \mathrm{~Hz}$. The target reflectance is received by a single photodetector with interference filters in the red and near-infrared regions, independently of the ambient light conditions. The normalized difference vegetation index (NDVI) was calculated from the two reflectance measures separately, as: NDVI = $[(\rho \mathrm{NIR}-\rho \mathrm{Red}) /(\rho \mathrm{NIR}+\rho \mathrm{Red})]$, in which $\rho$ NIR is the reflectance at the near-infrared region; and $\rho$ Red is the reflectance at the red region.

The first assessment using the canopy sensor was performed when sugarcane plants reached an average stalk height of $0.3 \mathrm{~m}$, followed by a second measurement at $0.5-\mathrm{m}$ stalk height (Table 1). The plant stalk height was adopted as the main parameter because the number of days after cutting is rather susceptible to climate variations and the sugarcane phenological stages are not well defined (Amaral \& Molin, 2011).

In the first and second experiments, the assessment with the canopy sensor was carried out manually at a distance of $1.0 \mathrm{~m}$ from the crop canopy and the data was recorded at $1 \mathrm{~Hz}$. In the third and fourth 
experiments, a set of two canopy sensors was mounted on a high-clearance vehicle, model Uniport 3000 NPK (Máquinas Agrícolas Jacto, Pompéia, SP, Brazil), keeping the same distance from the canopy. In both experiments, at least 20 NDVI values per plot were obtained, and the average value represented the respective plot. Regardless of how the assessments with the sensor were carried out, the travel speed was about $3.0 \mathrm{~m} \mathrm{~s}^{-1}$, excluding speed during sensing as a source of variation.

In the first, second, and third experiments, stalk yield was obtained separately for each plot by means of manual harvest of raw sugarcane, weighed using a loader equipped with load cells, whereas, in the fourth experiment, sugarcane was mechanically harvested and weighed using a truck equipped with load cells.

Yield and NDVI measurements were subjected to analysis of variance (Anova) using the SAS software (SAS Institute Inc., Cary, NC, USA). When the results were significant by Anova, at 5\% probability, regression analyses were performed using the SigmaPlot software (SPSS Inc., Chicago, IL, USA).

In order to quantify the crop response to $\mathrm{N}$ fertilization, the response index (RI) initially proposed by Johnson \& Raun (2003) was used. These authors verified the effectiveness of the RI in estimating crop response to applied treatments. The RI can be calculated for crop yield as well as for any other variable that is a function of the treatments. In the present study, the adopted variables were stalk yield and NDVI for each experimental unit. The RI was calculated as: $\mathrm{RI}=\mathrm{Var}_{\mathrm{ref}} / \operatorname{Var}_{\text {cont }}$, in which $\mathrm{Var}_{\mathrm{ref}}$ corresponds to stalk yield or to the NDVI values obtained for the highest $\mathrm{N}$ rate treatment; and $\mathrm{Var}_{\text {cont }}$ corresponds to the values obtained for the control treatment.
Several other indices similar to the RI have been developed in order to assess crop response to intermediate $\mathrm{N}$ rates. Lofton et al. (2012a) proposed a modification to the RI: instead of one single reference rate $\left(\mathrm{RI}_{\text {mod }}\right)$ being adopted, a $\mathrm{RI}$ value is calculated for each treatment. The $\mathrm{RI}_{\text {mod }}$ values were calculated separately for each experimental $\mathrm{N}$ rate plot using the following equation and were later subjected to regression analysis: $\mathrm{RI}_{\text {mod }}=\mathrm{Var}_{\text {rates }} / \mathrm{Var}_{\text {cont }}$, in which $\mathrm{Var}_{\text {rates }}$ corresponds to stalk yield or to the NDVI values individually obtained for each $\mathrm{N}$ treatment ( $\mathrm{N}$ rates); and $\operatorname{Var}_{\text {cont }}$ corresponds to the values obtained for the control treatment.

Essentially, the main methodological difference between the $\mathrm{RI}_{\text {mod }}$ and the standard $\mathrm{RI}$ is the possibility of estimating the increment in yield by the application of increasing $\mathrm{N}$ rates. The $\mathrm{RI}_{\text {mod }}$ allows obtaining response patterns that may have a maximum plateau, which may or may not be followed by a decrease in yield with higher $\mathrm{N}$ rates. Therefore, this index may be particularly useful in sugarcane in which the highest $\mathrm{N}$ rate does not necessarily relate to the highest yield, as stressed by Lofton et al. (2012a).

Independently of the index calculated, values higher than 1.0 indicate crop response to $\mathrm{N}$ application. Each one tenth of one unit above 1.0 indicates a proportional increase, i.e., a RI of 1.1 means that a $10 \%$ increase in yield was obtained through $\mathrm{N}$ application at the assessed rate.

\section{Results and Discussion}

In the first and second experiments, there was no interaction between sugarcane variety and $\mathrm{N}$ rate ( $>0.05$ ); however, a linear response to applied $\mathrm{N}$ was

Table 1. Experimental conditions, nitrogen fertilization dates (NF) and time intervals (days) between fertilization (F), canopy sensor measurements $(\mathrm{A})$, and harvest $(\mathrm{H})$.

\begin{tabular}{|c|c|c|c|c|c|c|c|c|c|c|}
\hline \multirow{2}{*}{$\begin{array}{l}\text { Expe- } \\
\text { riment }\end{array}$} & \multirow[t]{2}{*}{ Varieties } & \multirow[t]{2}{*}{ Ratoon $^{(1)}$} & \multirow[t]{2}{*}{ Soil $^{(2)}$} & \multirow[t]{2}{*}{$\mathrm{EPP}^{3}$} & \multirow{2}{*}{$\begin{array}{l}\text { Clay content } \\
\left(\mathrm{g} \mathrm{kg}^{-1}\right)^{(4)}\end{array}$} & \multirow[t]{2}{*}{$\mathrm{NF}^{(5)}$} & \multicolumn{4}{|c|}{ Time intervals (days) } \\
\hline & & & & & & & $\mathrm{F}$ to $1^{\text {st }} \mathrm{A}$ & $\mathrm{F}$ to $2^{\text {nd }} \mathrm{A}$ & $1^{\text {st }} \mathrm{A}$ to $\mathrm{H}$ & $2^{\text {nd }} \mathrm{A}$ to $\mathrm{H}$ \\
\hline 1 & SP81 3250, IAC87 3396, CTC14 & 2 & Haplustalf & $\mathrm{B}$ & 500 & $10 / 10 / 2011$ & 29 & 67 & 237 & 199 \\
\hline 2 & SP81 3250, IAC95-5000, RB 855536 & 2 & Hapludox & $\mathrm{B}$ & 200 & $10 / 15 / 2011$ & 30 & 63 & 303 & 270 \\
\hline 3 & CTC2 & 4 & Haplustox & $\mathrm{C}$ & 490 & $11 / 30 / 2011$ & 25 & 55 & 186 & 156 \\
\hline 4 & RB 867515 & 4 & Hapludox & $\mathrm{B}$ & 620 & $10 / 17 / 2011$ & 35 & 83 & 195 & 147 \\
\hline
\end{tabular}

${ }^{(1)}$ Cumulative number of harvests performed in the field for the experimental year. ${ }^{(2)}$ According to the Brazilian soil classification system (Santos et al., 2006), the soils are classified as: Argissolo Vermelho eutrófico (Haplustalfs) in the first experiment, Latossolo Vermelho eutrófico (Hapludox) in the second and fourth experiments, and Latossolo Vermelho-Amarelo distrófico (Haplustox) in the third experiment. ${ }^{(3)} \mathrm{EPP}$, environmental production potential according to Prado (2005). ${ }^{(4)}$ Soil sampled at $0-0.2-\mathrm{m}$ depth. ${ }^{(5)}$ The period between the previous harvest and $\mathrm{N}$ fertilization was less than 15 days. 
only observed in these two experiments (Table 2). No significant yield response to $\mathrm{N}$ was found in the third and fourth experiments carried out in Pradópolis, although higher $\mathrm{N}$ rates were used than in the first and second ones. Two factors might have contributed to this result in the third and fourth experiments: age of the sugarcane crop (fourth ratoon), considering that consecutive harvests usually result in damage to plants and due to the possible presence of limiting factors to crop development, such as soil compaction and other nutritional deficiencies, which can lead to low yield as observed in the fourth experiment, with average yield around $60 \mathrm{Mg} \mathrm{ha}^{-1}$, regardless of $\mathrm{N}$ application; and the fact that these areas are commercial sugarcane fields that have been cultivated with sugarcane for several years, which could have allowed $\mathrm{N}$ provision from other sources.

The lack of response of sugarcane to $\mathrm{N}$ fertilizer in particular years is not unusual, and similar behavior has been reported in other studies (Thorburn et al., 2003; Ishikawa et al., 2009; Lofton et al., 2012a; Amaral \& Molin, 2014). This can be attributed to the following factors: alternative $\mathrm{N}$ sources other than $\mathrm{N}$ fertilizers (Thorburn et al., 2003), such as mineralization of soil organic matter (Gava et al., 2005) and $\mathrm{N}$ fixation by diazotroph bacteria (Boddey et al., 2003; Schultz et al., 2012); age of sugarcane represented by the number of cuttings; water stress in specific stages (Lofton et al., 2012a); low $\mathrm{N}$ use efficiency of different $\mathrm{N}$ sources (Franco et al., 2011); and presence of other limiting factors to the crop development (Zillmann et al., 2006). However, in the present study, the data set of the four replicated field experiments, with varying responses to $\mathrm{N}$, were adequate to test the canopy sensor.

For each site, the results obtained from both readings at the stalk heights of 0.3 and $0.5 \mathrm{~m}$ showed similar $\mathrm{N}$ response trends, except in the second experiment (Table 3). In this experiment, the second sensor measurement indicated significant differences among $\mathrm{N}$ treatments, whereas the first reading did not. This could be explained by the reduced biomass accumulated at the $0.3-\mathrm{m}$ assessment period, which was evidenced by a higher coefficient of variation, as discussed by Amaral \& Molin (2011). Readings at an early stage may not be sensitive to show $\mathrm{N}$ response in sugarcane. Indeed, Amaral \& Molin (2014) used a similar canopy reflectance sensor in sugarcane and found that the ideal moment to take readings using this device is when the average stalk height is between 0.4 and $0.6 \mathrm{~m}$. Therefore, taking into account only the second measurement, as already shown for stalk yield, only the first and second experiments were identified as being responsive to $\mathrm{N}$ application using the canopy sensor.

Another important point associated to canopy sensor measurements is that the NDVI was not affected by the different varieties in any of the experiments conducted as split-plots (Table 3). This result contrasts with the necessity of specific calibrations, as suggested by Frasson et al. (2007), as a function of the morphological differences among the different varieties and their consequences in spectral behavior. Therefore, the factors that seem to influence canopy sensor readings the most are crop vigor and canopy volume, usually dependent on edaphic and climate conditions, rather than on factors associated with the cultivated variety, such as leaf color or plant architecture.

The regression analyses between $\mathrm{N}$ rates and NDVI were not significant in the third and fourth experiments, but showed linear response in the first experiment and quadratic response in the second one, in which maximum response was obtained at the $\mathrm{N}$ rate

Table 2. Stalk yield (fresh weight) as a function of $\mathrm{N}$ rate $\left(0,50,60,100,120,150,180\right.$, and $\left.240 \mathrm{~kg}^{-1}\right)$ and parameters of statistical analysis.

\begin{tabular}{|c|c|c|c|c|c|c|c|c|c|c|c|c|}
\hline \multirow[t]{2}{*}{ Experiment } & \multicolumn{8}{|c|}{ Stalk yield $\left(\mathrm{Mg} \mathrm{ha}^{-1}\right)$} & \multirow{2}{*}{$\begin{array}{l}\text { Anova } \\
\text { p value }\end{array}$} & \multirow{2}{*}{$\begin{array}{l}\mathrm{CV} \\
(\%)\end{array}$} & \multicolumn{2}{|c|}{ Linear regression } \\
\hline & 0 & 50 & 60 & 100 & 120 & 150 & 180 & 240 & & & $\mathrm{p}$ value & $\mathrm{R}^{2(1)}$ \\
\hline 1 & 65 & 69 & $-(2)$ & 74 & - & 78 & - & - & 0.007 & 10.0 & 0.002 & 0.78 \\
\hline 2 & 112 & 114 & - & 120 & - & 130 & - & - & 0.001 & 7.1 & $<0.001$ & 0.91 \\
\hline 3 & 84 & - & 78 & - & 84 & - & 87 & 89 & 0.149 & 7.1 & $\mathrm{~ns}(3)$ & ns \\
\hline 4 & 67 & - & 64 & - & 62 & - & 59 & 60 & 0.128 & 7.4 & ns & ns \\
\hline
\end{tabular}

${ }^{(1)}$ Coefficient of determination. ${ }^{(2)} \mathrm{N}$ rate nonexistent in the experiment. ${ }^{(3)}$ Analysis was not performed because of the lack of response indicated by analysis of variance (Anova). ${ }^{\text {ns Nonsignificant. }}$ 
of $110 \mathrm{~kg} \mathrm{ha}^{-1}$ (Table 3). However, stalk yield increased linearly with $\mathrm{N}$ rates (Table 2 ). The difference obtained using the canopy sensor and stalk yield may be due to a late response to high $\mathrm{N}$ rates, after the assessment using the sensor. Another possible explanation is that the canopy sensor signal underwent saturation at the treatment with high $\mathrm{N}$ rates. Signal saturation occurs in situations with high leaf area, in which, despite increased biomass, NDVI remains unaltered since it has already reached its maximum value. However, Amaral $\&$ Molin (2014) observed that this effect tends to occur only at stalk heights above $0.6 \mathrm{~m}$, which suggests that the difference between NDVI and stalk yield could be a result of sugarcane late response to high $\mathrm{N}$ rates.

Since the canopy sensor is capable of identifying the effect of $\mathrm{N}$ supply at an early sugarcane growth stage (Molin et al., 2010; Amaral \& Molin, 2011), which tends to be related to stalk production, it is also possible to use this device to determine the ideal $\mathrm{N}$ rate to be applied during crop growth, focusing on both maximum production and optimal economic return (Kitchen et al., 2010). In order to achieve this, it would be necessary to measure the crop response to $\mathrm{N}$ during the growing season. For that, it might be necessary to establish calibration experiments within each sugarcane field, as proposed by Raun et al. (2008) and Kitchen et al. (2010), who carried out mini-experiments for maize (Zea mays L.) and wheat (Triticum aestivum L.) crops, in which a few $\mathrm{N}$ rates could be applied just after sugarcane harvest. According to Amaral \& Molin (2014), at the ideal moment for assessing the plants with the canopy sensor, when stalk height is between 0.4 and $0.6 \mathrm{~m}$, regression analysis of the NDVI data would be able to identify the $\mathrm{N}$ rate that could provide the highest response. The identified $\mathrm{N}$ rate would then be applied to the remaining area (unfertilized crop). In this sense, the canopy sensor would only be used to estimate the crop response to $\mathrm{N}$ fertilization in a given field - as done by Hurtado et al. (2011) with a portable chlorophyll meter on a maize crop under Brazilian conditions - , instead of to direct the variable-rate $\mathrm{N}$ application, which is the main objective of this type of device.

The second assessment using the canopy sensor at the $0.5-\mathrm{m}$ stalk height showed the best results regarding $\mathrm{N}$ rate differentiation (Table 3 ), which is in alignment with Amaral \& Molin (2014). Therefore, only the data from this assessment were used to evaluate the sugarcane yield predicted by the canopy sensor.

The canopy sensor measurements were efficient in predicting yield $(\mathrm{p}<0.1)$, although the individual fittings for each experiment $\left(\mathrm{R}^{2}\right)$ could only be considered reasonable (Table 4). However, the lowest fitting in the first and second experiments could be a reflection of the presence of varieties with different production potentials that could have responded in different ways to climate, soil, and management conditions throughout the crop cycle, resulting in different crop vigor and canopy volume in the same field. According to Frasson et al. (2007), the abovementioned statement on specific calibration sounds reasonable.

No relationship between NDVI and yield was observed when the data from the four evaluated areas were combined in a single analysis (Table 4). This absence was probably due to large differences in yield and crop development status as a function of sugarcane variety and soil and weather conditions of each field. This result shows the necessity of data normalization in order to develop a generalized prediction model for grain crops and sugarcane, respectively, as suggested by Raun et al. (2005) and Lofton et al. (2012b).

Table 3. Analysis of variance ( $\mathrm{p}$ value) and regression analysis of the normalized difference vegetation index (NDVI) obtained by the canopy sensor in two assessments at average stalk height of 0.3 and $0.5 \mathrm{~m}^{(1)}$.

\begin{tabular}{|c|c|c|c|c|c|c|c|c|}
\hline \multirow[t]{2}{*}{ Variation source } & \multicolumn{2}{|c|}{ Experiment 1} & \multicolumn{2}{|c|}{ Experiment 2} & \multicolumn{2}{|c|}{ Experiment 3} & \multicolumn{2}{|c|}{ Experiment 4} \\
\hline & $0.3 \mathrm{~m}$ & $0.5 \mathrm{~m}$ & $0.3 \mathrm{~m}$ & $0.5 \mathrm{~m}$ & $0.3 \mathrm{~m}$ & $0.5 \mathrm{~m}$ & $0.3 \mathrm{~m}$ & $0.5 \mathrm{~m}$ \\
\hline Treatment (T) & $<0.01$ & $<0.01$ & 0.99 & 0.04 & 0.83 & 0.47 & 0.86 & 0.55 \\
\hline Variety (V) & 0.06 & 0.40 & 0.85 & 0.59 & $-(2)$ & - & - & - \\
\hline $\mathrm{T} \times \mathrm{V}$ & 0.38 & 0.67 & 0.18 & 0.36 & - & - & - & - \\
\hline Regression $^{(3)}$ & $\mathrm{L}^{* *}$ & $\mathrm{~L}^{* *}$ & $\mathrm{Q}^{* *}$ & ns & ns & ns & ns & $\begin{array}{l}\mathrm{ns} \\
\text { ns }\end{array}$ \\
\hline CV (\%) & 6.3 & 4.4 & 6.5 & 4.6 & 9.9 & 9.2 & 8.5 & 8.1 \\
\hline
\end{tabular}

${ }^{(1)}$ In the first and second experiments, the analysis was conducted as split-plots. ${ }^{(2)}$ Parameter not assessed. ${ }^{(3)} \mathrm{L}$ and Q indicate significant linear and quadratic responses, respectively. ${ }^{*}$ Significant at $1 \%$ probability. ${ }^{\text {nN}}$ Nonsignificant. 
One way to normalize the data is through the RI and using only the treatment that received the highest $\mathrm{N}$ rate, adopted as the reference rate, besides the control treatment. However, the crop response to $\mathrm{N}$ could be mistakenly estimated in cases in which the highest $\mathrm{N}$ rate does not result in the highest response of the plants to the fertilizer, as reported by Lofton et al. (2012a). This fact was not observed in the present study, so both forms of estimating crop response ( $\mathrm{RI}$ and $\mathrm{RI}_{\text {mod }}$ ) resulted in the same estimation of sugarcane response to the applied $\mathrm{N}$ (Table 5).

However, when the data from the canopy sensor for each experiment were transformed into $\mathrm{RI}_{\text {mod }}$ within each replicate (block), a higher significance of the correlation between yield and sensor readings was achieved (Table 6), in comparison to the absolute NDVI values (Table 4). This is because the normalization through $\mathrm{RI}_{\text {mod }}$ cancels out the discrepancy that might exist among the replicates. Moreover, Lofton et al. (2012a) claim that the $\mathrm{RI}_{\text {mod }}$ allows comparing nonhomogeneous experiments and improving the capacity of modeling yield when there is an absence of or a low response to $\mathrm{N}$ fertilization. Therefore, the better performance of the $\mathrm{RI}_{\text {mod }}$ could be understood in terms of the relations that contribute to build up the regression models, that is, in the $\mathrm{RI}_{\text {mod, the values }}$ from the control treatment (NDVI or yield) are taken into account in the calculation of all RI values, which corrects the results of lack of response obtained in some experiments.

The main advantage of the $\mathrm{RI}_{\text {mod }}$ is that it enables the estimation of yield by canopy sensor readings from generalized prediction models, since specific models for each situation generated after crop harvest would

Table 4. Regression equations, coefficient of determination $\left(\mathrm{R}^{2}\right)$, and regression significance ( $\mathrm{p}$ value) obtained between the normalized difference vegetation index (NDVI) and sugarcane stalk yield $\left(\mathrm{Mg} \mathrm{ha}{ }^{-1}\right)$ for each experiment separately and also for the combined analysis of the four evaluated areas.

\begin{tabular}{lccc}
\hline Experiment & Equation & $\mathrm{R}^{2}$ & $\mathrm{p}$-value \\
\hline 1 & Yield $=-46.506+(168.579 \mathrm{NDVI})$ & 0.466 & $<0.001$ \\
2 & Yield $=31.628+(120.227 \mathrm{NDVI})$ & 0.234 & 0.005 \\
3 & Yield $=60.437+(123.299 \mathrm{NDVI})$ & 0.666 & 0.092 \\
4 & Yield $=45.263+(24.045 \mathrm{NDVI})$ & 0.662 & 0.094 \\
\hline Combined & Yield $=-58.030+(533.504 \mathrm{NDVI})$ & 0.006 & 0.755 \\
\hline
\end{tabular}

not be useful to growers. Amaral \& Molin (2014) obtained good correlations between these variables by analyzing an index similar to the $\mathrm{RI}_{\text {mod, }}$, the sufficiency index (SI) proposed by Varvel et al. (1997) and adopted by Varvel et al. (2007) and Hurtado et al. (2011) in maize.

Due to the satisfactory results obtained by the normalized data, sugarcane response to a specific $\mathrm{N}$ rate could be estimated using the canopy sensor at a given crop management, estimated from generalized models. These generalized models could be developed from experimenting with $\mathrm{N}$ rates and using the $\mathrm{RI}_{\bmod }$ calculation. Once these models have been established, the growers could obtain RI values for each field using the canopy sensor reading during the growing season and then estimate the gain in yield that would result from $\mathrm{N}$ application.

In order to determine this estimate, it would be necessary not to apply $\mathrm{N}$ fertilizer on a small representative plot of the crop. At the ideal moment (Amaral \& Molin, 2014), canopy sensor readings would be taken at the nonfertilized plot and in a nearby

Table 5. Response index (RI) and modified response index $\left(\mathrm{RI}_{\mathrm{mod}}\right)$ obtained with stalk yield as a function of $\mathrm{N}$ rate $(50$, $60,100,120,150,180$, and $240 \mathrm{~kg} \mathrm{ha}^{-1}$ ) for each experiment.

\begin{tabular}{lcccccccc}
\hline Experiment & $\mathrm{RI}$ & \multicolumn{7}{c}{ Modified response index $\left(\mathrm{RI}_{\mathrm{mod}}\right)$} \\
\cline { 3 - 9 } & & 50 & 60 & 100 & 120 & 150 & 180 & 240 \\
\hline 1 & 1.20 & 1.06 & $-(1)$ & 1.14 & - & $1.20^{(2)}$ & - & - \\
2 & 1.16 & 1.02 & - & 1.07 & - & $1.16^{(2)}$ & - & - \\
3 & 1.06 & - & 0.93 & - & 1.00 & - & 1.03 & $1.06^{(2)}$ \\
4 & 0.89 & - & 0.95 & - & 0.92 & - & 0.88 & 0.89 \\
\hline
\end{tabular}

${ }^{(1)} \mathrm{N}$ rate nonexistent in the experiment. ${ }^{(2)}$ Values correspond to the $\mathrm{N}$ rates that provided the highest responses $(\mathrm{RI}>1.0)$.

Table 6. Regression equations, coefficient of determination $\left(\mathrm{R}^{2}\right)$, and regression significance ( $\mathrm{p}$ value) obtained between the $\mathrm{RI}_{\text {mod }}$ from the canopy sensor readings $\left(\mathrm{RI}_{\text {mod }} \mathrm{NDVI}\right)$ and from sugarcane stalk yield ( $\mathrm{RI}_{\text {mod }}$ Harvest) for each experiment separately.

\begin{tabular}{llcc}
\hline Experiment & Equation & $\mathrm{R}^{2}$ & $\mathrm{p}$ value \\
\hline 1 & $\mathrm{RI}_{\text {mod }}$ Harvest $=-1.386+\left(2.457 \mathrm{RI}_{\text {mod }} \mathrm{NDVI}\right)$ & 0.707 & 0.005 \\
2 & $\mathrm{RI}_{\text {mod }}$ Harvest $=-2.105+\left(3.188 \mathrm{RI}_{\text {mod }} \mathrm{NDVI}\right)$ & 0.744 & 0.027 \\
3 & $\mathrm{RI}_{\text {mod }}$ Harvest $=-0.387+\left(1.312 \mathrm{RI}_{\text {mod }} \mathrm{NDVI}\right)$ & 0.941 & 0.030 \\
4 & $\mathrm{RI}_{\text {mod }}$ Harvest $=0.739+\left(0.204 \mathrm{RI}_{\text {mod }} \mathrm{NDVI}\right)$ & 0.894 & 0.049 \\
\hline
\end{tabular}

Pesq. agropec. bras., Brasília, v.50, n.9, p.840-848, set. 2015 DOI: 10.1590/S0100-204X2015000900013 
plot that had been fertilized with $\mathrm{N}$ just after harvest. The next step would be to calculate the mean NDVI for each of these two plots and, from these data, the RI for the whole field. The RI yield would be estimated by means of the calculated RI (obtained from the sensor readings) in a predictive equation established using the $\mathrm{RI}_{\text {mod }}$ values (Figure 1) and by knowing the expected average yield for a given sugarcane field, which would allow the estimation of gain in yield with $\mathrm{N}$ application. However, this approach is difficult to implement in areas in which $\mathrm{N}$ is highly variable, since the response to $\mathrm{N}$ could vary within the field (Welsh et al., 2003; Zillmann et al., 2006).

Another limitation to this approach is that it does not indicate the ideal $\mathrm{N}$ rate to be applied; however, it is possible to infer whether the $\mathrm{N}$ application is being advantageous for a specific situation. Therefore, aiming for higher yield, the growers could decide whether to increase or decrease the top-dressing $\mathrm{N}$ fertilization rates according to the crop response to $\mathrm{N}$, using, for instance, regional fertilizer recommendations such as those given by Van Raij et al. (1997). However, in order to ensure the reliability of this approach, it is necessary to obtain better fitting models than the one used in the present study (Figure 1), since, according to Malley et al. (2004), models with fitting below 0.5 $\left(\mathrm{R}^{2}<0.5\right)$ should be considered unreliable.

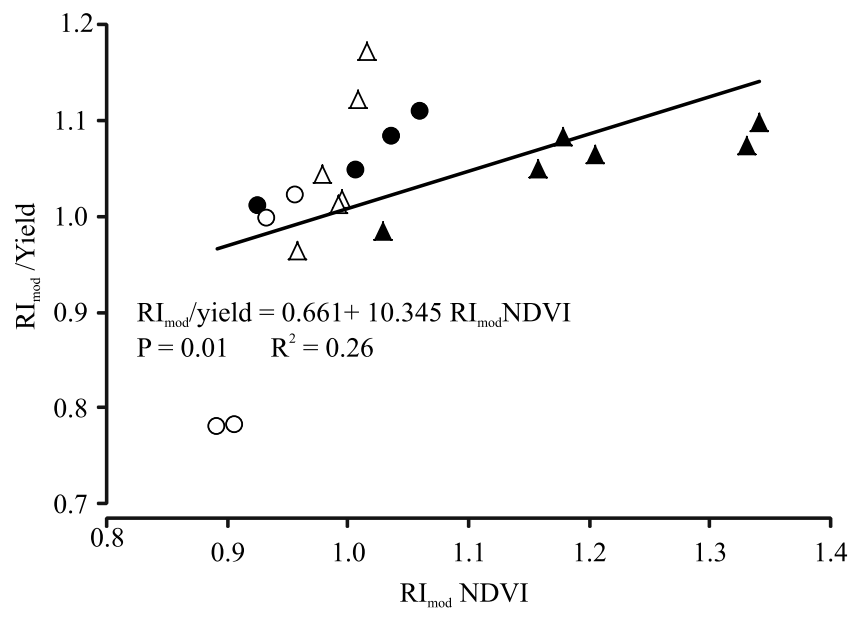

Experiment $1 \quad$ OExperiment $2 \Delta$ Experiment $3 \Delta$ Experiment 4

Figure 1. Relationship between the modified response index $\left(\mathrm{RI}_{\text {mod }}\right)$ estimated by means of sugarcane yield ( $\left.\mathrm{RI}_{\text {mod }} \mathrm{Yield}\right)$ and canopy sensor measurements ( $\left.\mathrm{RI}_{\bmod } \mathrm{NDVI}\right)$. NDVI, normalized difference vegetation index.

\section{Conclusions}

1. The canopy reflectance sensor could be an auxiliary tool to estimate sugarcane (Saccharum officinarum) response to $\mathrm{N}$ application, since it can be helpful in defining the $\mathrm{N}$ rate necessary to achieve sugarcane maximum production, using field calibration experiments.

2. Sugarcane responds differently to the $\mathrm{N}$ treatments in each of the four experiments, suggesting that the highest $\mathrm{N}$ rate does not always result in higher stalk yield, and, therefore, that the calculation of the response index that considers only the highest $\mathrm{N}$ rate might be problematic in quantifying the crop response to $\mathrm{N}$.

3. Although the modified response index can be used to develop a model capable of predicting yield gains due to $\mathrm{N}$ fertilization, even when the canopy sensor measures are collected up to 300 days before the harvest, prediction models with a better fit are necessary.

\section{Acknowledgments}

To Fundação de Amparo à Pesquisa do Estado de São Paulo (Fapesp, project number 2008/56.147-1), for financial support; and to Conselho Nacional de Desenvolvimento Científico e Tecnológico (CNPq, project number 311.197/2013-2), for scholarship grant.

\section{References}

AMARAL, L.R. do; MOLIN, J.P. Sensor óptico no auxílio à recomendação de adubação nitrogenada em cana-de-açúcar. Pesquisa Agropecuária Brasileira, v.46, p.1633-1642, 2011. DOI: $10.1590 / \mathrm{S} 0100-204 X 2011001200008$.

AMARAL, L.R. do; MOLIN, J.P. The effectiveness of three vegetation indices obtained from a canopy sensor in identifying sugarcane response to nitrogen. Agronomy Journal, v.106, p.273-280, 2014. DOI: 10.2134/agronj2012.0504.

BODDEY, R.M.; URQUIAGA, S.; ALVES, B.J.R.; REIS, V. Endophytic nitrogen fixation in sugarcane: present knowledge and future applications. Plant and Soil, v.252, p.139-149, 2003. DOI: 10.1023/A:1024152126541.

CANTARELLA, H. Nitrogênio. In: NOVAIS, R.F.; ALVAREZ V., V.H.; BARROS, N.F.; FONTES, R.L.F.; CANTARUTTI, R.B.; NEVES, J.C.L. (Ed.). Fertilidade do solo. Viçosa: Sociedade Brasileira de Ciência do Solo, 2007. p.375-470.

CANTARELLA, H.; TRIVELIN, P.C.O.; VITTI, A.C. Nitrogênio e enxofre na cultura da cana-de-açúcar. In: YAMADA, T.; 
ABDALLA, S.R.S.; VITTI, G.C. (Ed.). Nitrogênio e enxofre na agricultura brasileira. Piracicaba: IPNI Brasil, 2007. p.355-412.

FRANCO, H.C.J.; OTTO, R.; FARONI, C.E.; VITTI, A.C.; OLIVEIRA, E.C.A. de; TRIVELIN, P.C.O. Nitrogen in sugarcane derived from fertilizer under Brazilian field conditions. Field Crops Research, v.121, p.29-41, 2011. DOI: 10.1016/j. fcr.2010.11.011.

FRASSON, F.R.; MOLIN, J.P.; POVH, F.P.; SALVI, J.V. Temporal behavior of NDVI measured with an active optical sensor for different varieties of sugarcane. Revista Brasileira de Engenharia de Biossistemas, v.1, p.237-244, 2007. DOI: 10.18011/bioeng2007v1n3p237-244.

GAVA, G.J. de C.; TRIVELIN, P.C.O.; VITTI, A.C.; OLIVEIRA, M.W. de. Urea and sugarcane straw nitrogen balance in a soil-sugarcane crop system. Pesquisa Agropecuária Brasileira, v.40, p.689-695, 2005. DOI: 10.1590/ S0100-204X2005000700010.

GAVA, G.J. de C.; TRIVELIN, P.C.O.; VITTI, A.C.; OLIVEIRA, M.W. de. Recuperação do nitrogênio $\left({ }^{15} \mathrm{~N}\right)$ da ureia e da palhada por soqueira de cana-de-açúcar (Saccharum spp.). Revista Brasileira de Ciência do Solo, v.27, p.621-630, 2003. DOI: 10.1590/S0100-06832003000400006.

HURTADO, S.M.C.; RESENDE, A.V. de; SILVA, C.A.; CORAZZA, E.J.; SHIRATSUCHI, L.S. Clorofilômetro no ajuste da adubação nitrogenada em cobertura para o milho de alta produtividade. Ciência Rural, v.41, p.1011-1017, 2011. DOI: 10.1590/S0103-84782011005000074.

ISHIKAWA, S.; ANDO, S.; SAKAIGAICHI, T.; TERAJIMA, Y.; MATSUOKA, M. Effects of high nitrogen application on the dry matter yield, nitrogen content and nitrate-N concentration of sugarcane. Soil Science and Plant Nutrition, v.55, p.485-495, 2009. DOI: 10.1111/j.1747-0765.2009.00381.x.

JOHNSON, G.V.; RAUN, W.R. Nitrogen response index as a guide to fertilizer management. Journal of Plant Nutrition, v.26, p.249-262, 2003. DOI: 10.1081/PLN-120017134.

KITCHEN, N.R.; SUDDUTH, K.A.; DRUMMOND, S.T.; SCHARF, P.C.; PALM, H.L.; ROBERTS, D.F.; VORIES, E.D. Ground-based canopy reflectance sensing for variable-rate nitrogen corn fertilization. Agronomy Journal, v.102, p.71-84, 2010. DOI: 10.2134/agronj2009.0114.

LOFTON, J.; TUBANA, B.S.; KANKE, Y.; TEBOH, J.; VIATOR, $\mathrm{H}$. Predicting sugarcane response to nitrogen using a canopy reflectance-based response index value. Agronomy Journal, v.104, p.106-113, 2012a. DOI: 10.2134/agronj2011.0254.

LOFTON, J.; TUBANA, B.S.; KANKE, Y.; TEBOH, J.; VIATOR, H.; DALEN, M. Estimating sugarcane yield potential using an inseason determination of normalized difference vegetative index. Sensors, v.12, p.7529-7547, 2012b. DOI: 10.3390/s120607529.

MALLEY, D.F.; MARTIN, P.D.; BEN-DOR, E. Application in analysis of soils. In: ROBERTS, C.A.; WORKMAN JR., J.W.; REEVES III, J.B. (Ed.). Near-infrared spectroscopy in agriculture. Madison: American Society of Agronomy, 2004. p.729-784.
MOLIN, J.P.; FRASSON, F.R.; AMARAL, L.R.; POVH, F.P.; SALVI, J.V. Capacidade de um sensor ótico em quantificar a resposta da cana-de-açúcar a doses de nitrogênio. Revista Brasileira de Engenharia Agrícola e Ambiental, v.14, p.1345-1349, 2010. DOI: 10.1590/S1415-43662010001200014.

MULlEN, R.; LABARGE, G.; DIEDRICK, K. Temporal variability of crop response to fertilizer. Better Crops, v.94, p.16-17, 2010.

OLFS, H.-W.; BLANKENAU, K.; BRENTRUP, F.; JASPER, J.; LINK, A.; LAMMEL, J. Soil- and plant-based nitrogen fertilizer recommendations in arable farming. Journal of Plant Nutrition and Soil Science, v.168, p.414-431, 2005. DOI: 10.1002/ jpln.200520526.

PRADO, H. do. Ambientes de produção de cana-de-açúcar na região Centro-Sul do Brasil. Informações Agronômicas, n.110, p.12-17, 2005. Encarte.

PRADO, R. de M.; PANCELLI, M.A. Resposta de soqueiras de cana-de-açúcar à aplicação de nitrogênio em sistema de colheita sem queima. Bragantia, v.67, p.951-959, 2008. DOI: 10.1590/ S0006-87052008000400018.

RAUN, W.R.; SOLIE, J.B.; STONE, M.L.; MARTIN, K.L.; FREEMAN, K.W.; MULLEN, R.W.; ZHANG, H.; SCHEPERS, J.S.; JOHNSON, G.V. Optical sensor-based algorithm for crop nitrogen fertilization. Communications in Soil Science and Plant Analysis, v.36, p.2759-2781, 2005. DOI: 10.1080/00103620500303988.

RAUN, W.R.; SOLIE, J.B.; TAYLOR, R.K.; ARNALL, D.B.; MACK, C.J.; EDMONDS, D.E. Ramp calibration strip technology for determining midseason nitrogen rates in corn and wheat. Agronomy Journal, v.100, p.1088-1093, 2008. DOI: 10.2134/agronj2007.0288N.

SANTOS, H.G. dos; JACOMINE, P.K.T.; ANJOS, L.H.C. dos; OLIVEIRA, V.A. de; OLIVEIRA, J.B. de; COELHO, M.R.; LUMBRERAS, J.F.; CUNHA, T.J.F. (Ed.). Sistema brasileiro de classificação de solos. 2.ed. Rio de Janeiro: Embrapa Solos, 2006. 306p.

SCHULTZ, N.; MORAIS, R.F. de; SILVA, J.A. da; BAPTISTA, R.B.; OLIVEIRA, R.P.; LEITE, J.M.; PEREIRA, W.; CARNEIRO JÚNIOR, J. de B.; ALVES, B.J.R.; BALDANI, J.I.; BODDEY, R.M.; URQUIAGA, S.; REIS, V.M. Avaliação agronômica de variedades de cana-de-açúcar inoculadas com bactérias diazotróficas e adubadas com nitrogênio. Pesquisa Agropecuária Brasileira, v.47, p.261-268, 2012. DOI: 10.1590/ S0100-204X2012000200015.

THORBURN, P.J.; DART, I.K.; BIGGS, I.M.; BAILLIE, C.P.; SMITH, M.A.; KEATING, B.A. The fate of nitrogen applied to sugarcane by trickle irrigation. Irrigation Science, v.22, p.201-209, 2003. DOI: 10.1007/s00271-003-0086-2.

THORBURN, P.J.; MEIER, E.A.; PROBERT, M.E. Modeling nitrogen dynamics in sugarcane systems: recent advances and applications. Field Crops Research, v.92, p.337-351, 2005. DOI: 10.1016/j.fcr.2005.01.016.

VAN RAIJ, B. Fertilidade do solo e manejo de nutrientes. Piracicaba: IPNI, 2011. 420p. 
VAN RAIJ, B.; CANTARELLA, H.; QUAGGIO, J.A.; FURLANI, A.M.C. Recomendações de adubação e calagem para o Estado de São Paulo. Campinas: Instituto Agronômico: Fundag, 1997. (IAC. Boletim técnico, 100).

VARVEL, G.E.; SCHEPERS, J.S.; FRANCIS, D.D. Ability for in-season correction of nitrogen deficiency in corn using chlorophyll meters. Soil Science Society of America Journal, v.61, p.1233-1239, 1997. DOI: 10.2136/sssaj1997.036159950061 $00040032 x$.

VARVEL, G.E.; WILHELM, W.W.; SHANAHAN, J.F.; SCHEPERS, J.S. An algorithm for corn nitrogen recommendations using a chlorophyll meter based sufficiency index. Agronomy Journal, v.99, p.701-706, 2007. DOI: 10.2134/agronj2006.0190.

WELSH, J.P.; WOOD, G.A.; GODWIN, R.J.; TAYLOR, J.C.; EARL, R.; BLACKMORE, S.; KNIGHT, S.M. Developing strategies for spatially variable nitrogen application based in cereals. Biosystems Engineering, v.84, p.495-511, 2003. DOI: 10.1016/S1537-5110(03)00003-5.

ZILLMANN, E.; GRAEFF, S.; LINK, J.; BATCHELOR, W.D.; CLAUPEIN, W. Assessment of cereal nitrogen requirements derived by optical on-the-go sensors on heterogeneous soils. Agronomy Journal, v.98, p.682-690, 2006. DOI: 10.2134/ agronj2005.0253.

Received on February 5, 2015 and accepted on July 20, 2015 